\title{
Filial Piety Education for VietNamese Students Today
}

\author{
Associate. Professor. Dr. Tran Đang Sinh \\ Hanoi National University of Education, Viet Nam \\ PhD student Mai Trong An Vinh \\ Hanoi National University of Education, Viet Nam
}

\begin{abstract}
The Vietnamese people have many precious and traditional moral values, including the filial piety tradition. filial piety demonstrates the moral and willful life ethic, is the way of life of Vietnamese people. It is the philosophy of gratitude expressed most concentrated in the thought of filial piety. filial piety was started from family education. The family is the first, basic and most decisive environment in the education of filial piety religion. Filial piety is a feeling, a duty that arises in feelings, thoughts, thoughts, and manifestations through actions towards grandparents, parents of children. Filial piety is an indispensable quality of human, which is a natural truth in life, so it is automatically called filial piety. filial piety can be understood as an obedient, successful child, inheriting the career of his parents, promoting the fine traditions of the clan, honoring grandparents, parents.
\end{abstract}

Keywords: Education, morality, dogma, student Viet Nam, Grateful.

DOI: $10.7176 / \mathrm{JEP} / 12-6-07$

Publication date: February $28^{\text {th }} 2021$

\section{Preamble}

For the Vietnamese people, filial piety is a fundamental moral quality, demonstrating the ethic of drinking water, remembering its source. In today's society there is a part of students who live indifferent, pragmatic, lack of ideal, ambition, dreams, disrespect to filial piety, no gratitude to their parents, their homeland, the thanks of Party, of the revolution. Therefore, the education of the ethics of drinking water to remember the source for Vietnamese students is now an urgent job, contributing to bringing the Central Party's Resolution XI to life.

\section{Research content}

2.1. Filial piety is the manifestation of the most focused ethics of drinking water, remember the source The Vietnamese people have many precious and traditional moral values, including the tradition when drinking water, remember its source. When drinking water, remember the source expressing the moral of life and will, which is the way of life of Vietnamese people.

The idiom when drinking water, remember its source, takes an everyday image and summarizes it into a universal moral quality of the Vietnamese people. Drinking water to remember its source is the philosophy of gratitude expressed most concentrated in the thought of filial piety. Filial piety was started from family education. Family is the first, basic and most decisive environment in educating filial piety.

- Filial piety is a feeling, a duty that arises in feelings, thoughts, thoughts, and manifestations through actions towards grandparents, parents of children. Filial piety is an indispensable quality of human, which is a natural truth in life, so it is automatically called filial piety. Filial piety can be understood:

- Filial piety is gratitude, taking care of grandparents, parents while living, worshiping when dead

- Honor is respect and obedience to your parents' words

- Filial piety is consensus that brothers and sisters in the house love each other and help each other in harmony

- Filial piety is filial to his parents, loyal to the king (the representative of the nation of the feudal nation), now Filial piety is understood more broadly than filial piety, loyal to the country.

Confucianism said that filial piety has 3 levels:

- Filial piety (respectful), is the respect and nurturing of parents and grandparents while living and worshiping when they die.

- Filial piety (Regardless of Filial piety), is a child who does not age so that his parents will be sad.

- Filial piety, is an obedient, successful child, inherits his parents' career, promotes good traditions of the clan, honors his grandparents and parents.

\subsection{Filial piety in folk culture}

In folk cultural treasures, filial piety is highly regarded as an eternal value. There are many sentences about filial piety and the explanation why children must practice filial piety:

"The father as a mountain

Mother is like water flowing out of the source " 
Parents such a noble grace, being a son is first of all to be obedient to their parents:

"Mom and Dad is the sea, it's heaven

How dare I obey my parents"

When growing up, when they are aware of the parents' merits of birth and hardship, they must be deeply impressed with their deep gratitude:

"Thank you very much, father

Mother is equal to heaven, nine months pregnant "

Being a child, was raised and raised not only by rice, but also grown up in the immense love of the father and mother. The mother gives her all by lullabies, day and night, hoping for a great success for her son, and for girls, she will help her husband to create fame and wealth.

When children grow up, become parents and nurture their children, then they will fully realize the merits of their parents:

"You can only feel it when you do it

Only after raising children can know the sample merits "

Regardless of the circumstances of the situation, the mother's heart is still boundless in her dear child:

"Old mother in that cottage

Visiting early, at night to visit, I have to do "

The moral counsel of the nation is:

"Whether to worship your father

Do not sound heavy, people laugh at"

If you take care of your parents, you must know to take care of the word filial piety:

"One Heart Worship Mother Glass Father,

To round the word filial piety is the son"

Brothers in the family need to get along well:

"You are not outsiders

Chickens and a mother always fight each other "

Bearing in mind the nostalgia of love and care when parents are still alive, when their parents are away from the mountain, they still have a feeling of love, respect and worship:

"Determined to set up a temple to touch the dragon

Thanks to the mother holding the old days "

Besides the filial children who know how to worship their father, there are also those who do not fulfill the filial piety religion. In order to educate these people, his fathers had to say:

"Parents raise their children by the sky

I take care of my mother every day"

Thus, it can be said that the education of filial piety religion in the traditional Vietnamese family has always received attention. Through the education of filial piety, the ethic of drinking water, remember its source, repaying the meaning permeates the Vietnamese people's consciousness since childhood and followed them throughout their life.

Filial piety is not only confined to family but also expanded to neighborhoods and villages. That is why the ancient people taught: "Sell brothers far away, buy neighbors near", neighbors "turn off the fire at night, the lights together", "good leaves protect torn leaves". In the villages and communes, there are communal houses, temples and shrines to worship the village Citadel - people who have made merit to open the land, keep the village, teach jobs and teach words to the people. In the national community:

"Oh dear with the same pumpkin

Although other varieties but share a rig"

Ancestor worship is the manifestation of the moral of drinking water, remember the source. Phan Ke Binh said: "Considering the profanity of our ancestors is very respectful, it is also an immoral heart, also an act of people"1. According to Toan Anh: "To worship ancestors because of the gratitude of children and grandchildren to the dead parents, grandparents and grandparents" 2 .

Hung Vuong worship belief is the peak of ancestor worship, the crystallization of the ethic of drinking water, remember the nation's source. Remembering at Hung Temple, Uncle Ho instructed the soldiers of the Army Corps to take the vanguard when he moved to liberate the capital: "The Hung Kings have built the country, our Uncle and I must keep the country together" is an expression of high filial piety most of our generation with respect to Hung Vuong Fatherland. Every year on the national anniversary of the 10th of March, millions of Vietnamese people at home and abroad all turn to the Fatherland, commemorating the merit of the people who have made the country open. Recently, many provinces in the country have set up the temple to

1 Quoted under Phan Ke Binh (1995), Vietnamese customs, publishing company Ho Chi Minh city, page 20 -21.

2 Quoted under Toan Anh (1996), Vietnamese family worship customs, publishing company Native culture, Ha Noi, page 4. 
worship King Hung, partly meeting the need to repay the gratitude of the majority of people.

\subsection{Some solutions to educate filial piety for students today}

Currently, the trend of globalization including cultural globalization is creating both opportunities and challenges for nations and peoples. Vietnam is on the path of integration and development, while at the same time, it is necessary to selectively absorb the quintessence of human culture, while inheriting and developing traditional cultural values, including the ethic of drinking water, remember its source.

Currently, in society, some young people are showing signs of moral decline such as pragmatic life, lack of ideal, ambition, dream of establishing a career, refusing to study history, and an emotionless attitude , indifference, even denial of the past. Disobeying, mistreating parents, brothers at odds, fighting. In order to contribute to overcoming that situation, it is necessary to constantly educate traditional ethics, in which special attention is paid to the education of the ethics of drinking water, remember the source for today's youth.

To educate the ethics of drinking water, remember the source for today's young people, we need to focus on implementing the following solutions:

Firstly, raising awareness and responsibility for the whole society in the ethics of drinking water, remember the source for young people.

On the part of social organizations, it is necessary to expand social activities, such as through the mass media to propagate the traditional ethical values of the nation, to praise and exalt Filial examples from past to present. The State and unions need to expand the emulation movement, build a cultural family of exemplary parents, gentle children and grandchildren ... to help the young generation see the ethical practice of drinking water, remember its source Family is not only a responsibility but also an obligation of each member, building a loving relationship in the family.

The Party and State need to have specific guidance to the development of the family, both physically and mentally. The Resolution of the XI National Congress of the Party affirms the need to summarize and build a common value system of Vietnamese people in the period of accelerating industrialization, modernization and international integration. ${ }^{1}$

It is necessary to create a healthy social environment for family members to take care of and educate the children. Strive to build many cultural families, give, praise and promptly reward the filial examples in society.

Socio-economic policies that are close to real life, policy families, and families with meritorious services to the country must be considered carefully. Need to institutionalize into law specific standards on the phenomenon of non-Hieu, performing the obligations of children in the family in article 35, chapter 4 of the Law on Marriage and Family (2000): "You have the duty to love, respect, be grateful, be filial to your parents, listen to your parents' correct advice, preserve the family's traditional good honor. Children have the obligations and rights to care for and nurture their parents. Children are strictly forbidden to mistreat, abuse or offend their parents".

Second, promoting the active role of individuals in reporting filial piety

Along with the education of the family, the school and the society, each individual needs to realize the merit of being born and nurtured of his parents and always remind himself to practice good filial piety religion in the family.

The affection between parents and children in a family is a noble spiritual sentiment that is also a natural one. Parents nurture, love and take care of their children is as natural as their children's feelings of respect, love and gratitude towards their parents. Currently, due to the negative influence of the market economy, many people have been caught up in the cycle of fame and forget or have turned against Hieu in the family, so each person needs to always be self-conscious about public. parents' grace and the obligation to repay that heaven and earth.

Third, there is a need for close coordination between families, schools and society in educating the ethics of drinking water, remember the source for young people.

First of all, parents must recognize the responsibility of educating the ethics of drinking water, remembering its source for their children. Family is the first school. Parents are the first to teach children about gratitude to ancestors, grandparents, family traditions, the country.

In order to educate children to be filial with grandparents and parents, first of all parents must be filial children. Educating children about filial piety, parents can take filial examples in practice or in books. Besides, filial behavior in society also needs to be criticized.

Schools, need to further strengthen ethical education activities for students, closely combining family education and school education to have appropriate educational measures. Should widely launch the movement to do many good deeds, have scholarship funds for children from difficult families but study well, live filiality with their parents. The social organizations need through the mass media to propagate the traditional ethical values of the nation, to praise and praise the examples of filial piety from the past to present. Expand emulation

1 Quoted under Communist Party of Vietnam (2011), Document of the XI National Party Congress, publishing company Encyclopedic dictionary, Ha Noi, page 1049. 
movement, build exemplary grandparents, grandparents, and gentle descendants of culture.

The Party and State need to have specific guidance and policies towards the development of the family. Create more favorable conditions for parents to take care and educate their children in the best way. Strive to build cultural families, villages, wards and communes.

In recent years, the Party, the State and many social organizations have carried out practical activities to educate about the sense of roots, to practice the ethic of drinking water, remember the source for all people in general and young people. private. National level festival back to the source in Thai Nguyen, Super-praying ceremony for martyrs in Quang Tri, journeys back to the old battlefields, activities to find graves of martyrs of organizations and fish Humanity, adoption of martyrs' mothers of agencies and units, building gratitude houses for families with meritorious services to the revolution ... are living lessons demonstrating the ethic of gratitude of the Vietnamese people. July 27 every year is considered by Party agencies, governments at all levels, branches, social organizations and individuals as a day of spiritual significance for the nation, the most concentrated expression of drinking ethics. Water, remember its source, remember the person who planted the tree

In order to well implement the content of the moral education "Drink water, remember its source" for the young generation, it is necessary to have close coordination between family, school and society. Only when there is such a combination, can education bring about the highest results.

Fourthly, to expand the Ethics of drinking water, remember the source from the communal house to the village. Well implement the movement of building cultural neighborhoods and villages, bringing this movement to an increasingly improved quality to both keep up with modern life rhythm and promote national cultural identity.

\section{Conclusion}

In general, in historical and present Vietnamese society, gratitude to the former, the leaves fall to the roots, worship the ancestors, drink water, remember the source of good moral values is always preserved and promoted. However, due to many objective and subjective factors, a part of children have filial acts, including a large part of young people. requires the leaders of the party, authorities and mass organizations to have practical directions and solutions to educate the ethics of drinking water, remember the source for young people. That moral education contributes a small part to building moral and social ethics in general, for the young generation in particular in the current context of the country's renewal, integration and development.

Youth is the future of the country, the future belongs to the youth. Vietnamese youth in the light of Marxism-Leninism, Ho Chi Minh Thought, on the path of founding a career, not only knowledge, science and technology but also tradition in our luggage. The extremely precious culture of the nation is forged from thousands of years of history, including the ethic of drinking water, remember its source.

\section{REFERENCES}

1. Toan Anh (1996), Vietnamese family worship customs, publishing company Native culture, Ha Noi, page.4

2. Phan Ke Binh (1995), Vietnamese customs, publishing company Ho Chi Minh City, page. 20 -21.

3. Communist Party of Vietnam (2011), Document of the XI National Party Congress, publishing company Hanoi National Politics, page.124. 